\title{
Home Improvement Television: Holmes on Homes Makes It Right
}

\author{
Jean Bruce \\ Ryerson University
}

\begin{abstract}
Holmes on Homes is a Canadian home improvement television program and the centrepiece of HGTV (Home and Garden Television), featuring Mike Holmes as the series' star contractor and host. This paper argues that by looking back at earlier incarnations of film and television melodrama, we can determine the way in which Holmes on Homes reinvents the home improvement subgenre. By playing out reality TV's central tension between fiction and non-fiction, Holmes on Homes reveals its larger themes of justice and redemption, which befit its unique position between the documentary and the classic melodrama.
\end{abstract}

Keywords: Reality TV; Holmes on Homes; Home improvement television; Documentary TV; Classic melodrama

Résumé : Holmes on Homes, mettant en vedette l'entrepreneur Mike Holmes, est une émission canadienne sur l'amélioration du foyer et la pièce de résistance du réseau HGTV (Home and Garden Television). Cet article soutient que nous pouvons recourir à des exemples anciens de mélodrames à la télévision et au cinéma, pour déterminer la manière dont cette émission réinvente le sous-genre " amélioration du foyer ». En effet, Holmes on Homes, en développant les tensions centrales de la téléréalité entre fiction et vérité, révèle ses thèmes clés de justice de rédemption qui reflètent sa position unique entre documentaire et mélodrame classique.

Mots clés : Téléréalité; Holmes on Homes; Télévision sur l'amélioration du foyer; Télévision documentaire; Mélodrame classique

\section{Introduction}

When specialty network Home and Garden Television (HGTV) Canada applied for its broadcasting licence in 1996, the "nature of the service" it would provide was described as follows:

The licensee will offer a 24-hour-a-day specialty service devoted to programming that presents practical, hands-on advice and instruction about homes and gardens. The programming will revolve around five key

Jean Bruce is Assistant Professor in the School of Image Arts and Graduate Program in Communication \& Culture at Ryerson University, 350 Victoria Street, Toronto, ON M5B 2K3. Email: jbruce@ryerson.ca.

Canadian Journal of Communication, Vol 34 (2009) 79-94

(C)2009 Canadian Journal of Communication Corporation 
themes: building and remodelling, decorating and interior design, gardening and landscaping, crafts and hobbies and special interests (CRTC, 1996).

Owned by Alliance Atlantis Television until 2007, HGTV Canada is now part of Canwest Broadcasting and is a member of a worldwide family of Home and Garden Television networks that includes channels in the United States, the United Kingdom, Australia, and New Zealand, along with several dozen affiliates. In the last decade, such networks have been responsible for an explosion of home repair television programming. ${ }^{1}$

For seven years, Holmes on Homes has been a staple, and a star, in the lineup of HGTV Canada. ${ }^{2}$ Not only was the renovation television program craze in full swing as Holmes entered HGTV's spotlight in 2001, but the network and show also benefited from the 1999 Canadian Radio-television and Telecommunications Commission (CRTC) policy changes to broadcast content that offered "more flexibility, diversity and programming choice" (Canadian Radio-television and Telecommunications Commission, 1999). In particular, HGTV was in line with the CRTC's aim to broaden the definition of "priority" programming. Its prime-time priority mandate was to include "documentaries of 30 minutes or more, regional programs (other than news and sports) and programs which promote Canadian talent and successes here and abroad . . . in addition to drama, comedy, music and variety programs" (CRTC, 1999).

Although the CRTC licensing and programming literature has been interpreted loosely, the above changes altered the criteria for Canadian television sufficiently to include reality-based home improvement programming. ${ }^{3}$ This meant, in effect, that all Canadian reality television was under pressure from national policy and the global marketplace to find ways of telling stories that satisfied both. It is due in part to these combined changes that Holmes on Homes is able to situate itself in the fiction-non-fiction continuum that defines the reality TV experience (Bruzzi, 2006; Hill, 2005). This article will explore some of the innovative ways that Holmes on Homes transforms the home improvement reality genre, specifically by refiguring the relationship between the melodrama and documentary modes of address that it deploys. The relative ease with which the show recasts aspects of these genres in the service of home improvement extends the category of reality TV. Moreover, its re-jigging of melodrama and documentary pays off for both domestic and foreign markets; this gives the show the flexibility to tell its uniquely Canadian story on the world stage in a manner that is familiar to all.

\section{Holmes on Homes: Let's Make It Right ${ }^{\mathrm{TM}}$}

While the narrative trajectory of Holmes on Homes has remained constant throughout the series, the first season of the show differed significantly in tone from more recent seasons. The formula of the program is as follows: Mike Holmes arrives and listens to the particular problems experienced by a set of homeowners. He then carefully inspects the previous work that has been completed by other contractors. Finally, Holmes discusses the defective workmanship assessed during his inspection and, in turn, vows to "make it right."

Originally, Holmes on Homes was a half-hour show, and Mike, as host and 
general contractor, arrived on site with a minimal crew and a truck with a small trailer filled with tools and supplies. He proceeded to do whatever repair was needed - that is, to provide and record practical hands-on advice befitting the HGTV licensing criteria. The style of the show's first season was also a more straightforward documentation of the process of discovery and repair of the home's problem. Today, however, there is no such modest way to encounter Mike Holmes. The style of the show, now an hour long, and the magnitude of the repairs have been ratcheted up to reflect Holmes' star status. If you believe everything you hear about the man, he has the ability to leap tall buildings in a single bound, fixing the crumbling foundation and leaking roof en route. Formerly, the repairs were small - just enough to fix the problem, without undertaking a major renovation. There was, nonetheless, plenty of emotion once the repair was complete, and this usually took the form of effusive thanks to Mike and his crew. By contrast, Holmes now manages his crew of several members, while additional experts are brought in to deal with specialty renovation issues. In the process of inspecting the work or during the repair itself, Holmes often discovers a more serious problem that requires his immediate attention. A line from an advertisement for the 2008 season reveals the new, escalated level of home repair that the show depicts: Mike says, "I've decided, now, to gut the whole thing."

In recent years, television advertisements for the show have depicted Mike in animated form, garbed in his signature costume-brown overalls and white undershirt - rescuing a damsel homeowner in distress. This image is intercut with live-action shots of "real" "rescues." While all of the sound-bite testimonials suggest that clients are satisfied with the renovations, the most compelling of these, I think, is the woman who says, "I do have faith in Holmes on Homes." 4 In fact, while Holmes has transformed from good-guy contractor to superman over the seven seasons of the show, his work has not ended there.

Recently, in a follow-up to a guest appearance on The Ellen DeGeneres Show, Mike and his crew went to California to repair a disastrous home renovation; this became a two-part Holmes on Homes episode called "Pasadena 911." And according to Canwest Broadcasting news, in spring 2009 we will be seeing a two-hour special of Mike and crew slogging away in New Orleans to help rebuild the city following Hurricane Katrina, an effort that includes Hollywood superstar Brad Pitt.

Meanwhile, Mike Holmes has written two how-to books on home repair and purchasing, Make It Right (2007) and The Holmes Inspection (2008), as well as a weekly advice column in The Globe and Mail; he has also made sponsorship arrangements with The Home Depot and others. Holmes has starred in publicservice announcements supporting education in the trades for the province of Nova Scotia and provides scholarships and bursaries for trades students across Canada. He has also established The Holmes Foundation to assist people bankrupted by bad renovations and unreliable contractors, and he acts as a spokesman for SOS Children's Fund for worldwide relief through building homes and schools. In addition to the t-shirts and key-chains available for sale online, Holmes is also developing an approved line of construction wear under the label Holmes Workwear. All of this suggests that Holmes is a recognizable cultural icon and institution, and that while home renovation advice may be the pretext for 
Holmes on Homes, the plot-line of each episode and the press surrounding Holmes are crafted carefully to elevate home repair to an epic, heroic intervention. The contractor has attained the rank of superhero-even saviour. As Holmes claims, "I'm gonna make it right."

The overall shift of the program along the fiction-non-fiction continuum of reality television suggests that Holmes' position within the program has also shifted, from the narrator/interviewer of a documentary toward a melodrama's leading man. Holmes on Homes has considerable appeal, judging by the show's prominence in the daily rotation of HGTV Canada programming and its worldwide affiliates. The popularity of Holmes on Homes is linked inextricably to its host's charisma, which is complemented by the show's unique version of home improvement reality TV. For example, most home improvement shows begin with some variation on the designer/decorator/contractor/handyman entering the client's home to discuss a wish list of improvements. This moment, according to convention, is depicted on-screen as an interview, which is a structural technique that is often returned to at crucial decision-making points throughout the improvement process (Everett, 2004). Holmes, by contrast, enters the home confident that his repair plan is already in place. Unlike other designer-decorators or contractor-handymen, he does not consult with the homeowners about structural or aesthetic details during the preliminary walk-through or later in the renovation process. ${ }^{5}$ He simply acknowledges, in passing, that he has been here before as he takes the clients (usually a husband and wife) through the extent of the repair he is planning in order to "make it right."

It is illuminating that "making it right," or restoring the home and its inhabitants to their rightful status is also the motivation driving the plots of many classic domestic melodramas, especially those made in 1950s Hollywood. In these films, some kind of threat is made to the home and family, and the narrative promise, which is made implicitly or explicitly by the hero-protagonist, is to reestablish order and equilibrium. In melodrama, the establishment of stability to the domestic space is often achieved through an indirect route and only after the virtuous protagonist has experienced several extreme emotional ups and downs that we witness. Things that happen in the home are indicative of other issues occurring outside it. The melodrama's tendency is to displace social, domestic, or familial anxieties into the mise-en-scène of the specific settings depicted (Elsaesser, 1991). The home is encoded with cultural significance within the melodrama, and the domestic space often provides a magnifying mirror for larger social issues. For example, conflict often occurs in the home when the desires of individuals are at odds with social convention, especially when these issues are difficult to articulate verbally or are even censored socially. ${ }^{6}$

Historically, the melodrama has migrated from literature and the stage to newspaper and radio, as well as film and television (Bratton, Cook, \& Gledhill, 1994; Brooks, 1976; Klinger, 1994; Thorburn, 2000). As a genre and mode of expression, its characteristics are numerous and sometimes difficult to define except broadly. As Linda Williams (2002) suggests,

melodrama is neither archaic nor excessive but a perpetually modernizing form. . . . By what better name . . . shall we refer to those novels, sto- 
ries, stage plays, movies, songs, and media events that move us to sympathy for the suffering of others? ... Its genius lies in its protean ability to "leap" across centuries and media, to make jaded readers, audiences, and viewers thrill to ever new forms of pathos and action. (p. 16)

Film and television melodramas tend to displace desires into the imagery of the home in order to personalize larger social issues. The melodrama articulates these issues by investing significance in ordinary household objects. Elements of the home's mise-en-scène, such as lighting, costuming, set design, and props, are all treated melodramatically, so that in the organization of the space, they can be read according to the subterranean or muted language of the melodrama. These elements are imbued with meaning according to the visual weight of objects and their placement and movement within the frame relative to other objects (Elsaesser, 1991).

Aural motifs are also expressed with varying degrees of subtlety in melodramas and can be anything from a recurring musical figure or sound effect to the soundtrack or theme music of a film or television melodrama. These, too, are layered with meaning according to the specific issues that individual narratives raise, and they often function as counterpoint. While theme music and lyrics are often used as aural motifs, in television programs, these also function to bridge gaps between commercials or form part of the aural register of an advertisement for the program itself. The repeated tagline "make it right" is a trademarked verbal and written motif of Holmes on Homes, but it is obviously more significant than just that. This tagline is also revealing in its simplicity, since Holmes' mission is repair, and any beautification that results is considered a bonus, which he often dismisses or at least downplays. ${ }^{7}$

Unlike in the domestic melodrama or other home improvement shows, there is relatively little in the manner of weighted objects to convey additional meaning in Holmes on Homes. Since Holmes' aim is less to renovate than to "rescue" the space, decoration rarely enters the equation at all. The single most important feature of home improvement shows is the spectacle of the "reveal," which signals the end of the show. The fixed elements of the underlying structural or renovation work completed, which have been depicted on-screen to varying degrees, are complemented by unfixed decorative elements - everything from furniture choices and small appliances to flowers and table settings. While no two home improvement shows adopt exactly the same strategies in the reveal, most shows place the greatest emphasis there. ${ }^{8}$ In contrast, at the end of Holmes on Homes, the couple is taken on a tour through the newly rescued space of their home while Holmes tells them in great detail what the crew has accomplished, much of it hidden from view. Often using the technical language of various trades, he stresses his own expertise, as well as the effort of the specialized work required to undertake the repair. In effect, Holmes reminds us that the structural integrity underlying all the bare-bones (in comparison with other shows) surface beauty of these fixed elements is the most important thing.

The home's structural elements are the recurring masculine motifs of this melodrama. Linda Williams argues that "pathos plus action" is the central driving force of the melodrama toward its conclusion (2002, p. 16), but this also aptly 
describes the movement between the documentary and melodramatic tones of Holmes on Homes. The male melodrama often involves displays of bravery, strength, chivalry, precision, specialized knowledge, and order, and these same values are invested in the wounded homes depicted on Holmes on Homes. Those silent, hidden structural elements that are the foundation of the home are restored to their proper state of repair. But by borrowing conventions from documentary at significant moments in the show, Holmes also taps into the sobriety of documentary discourse (Nichols, 1991).

In the interview-witnessing moment of the reveal, Holmes' word stands in for the images of repair we have seen previously. His authority is maintained throughout this process, and he alone assigns meaning to the "objects" he unveils within the home. But this authority is also achieved in part through the low-angle shots and back lighting that frame his blond buzz-cut to create a halo effect. Altogether in this context, these textual elements tend to deify Holmes. His image as saviour is now realized completely, and all that remains is to reunite the grateful homeowners with their home. Throughout this reveal process, sombre electronic keyboard music played in simple, descending minor chords fills the background, and the aural motif of the show emphasizes subtly the principled seriousness of Holmes' mission. This moment returns us once again to the melodrama; the "music plus drama"-which defines the genre literally-aurally underscores the morally righteous tone of the improvement project and the overall impact of the repair/rescue.

\section{Holmes on Homes: The evolution of home improvement}

Mike Holmes' eminence as a Canadian cultural and consumer icon cannot be ignored. Holmes on Homes both adheres to and inverts aspects of the home improvement subgenre, ensuring the popularity of "the brand" and its ability to remain generically stable yet reinvent itself slightly with each new episode. While this is due in part to invoking classic elements of melodrama, it is also achieved by placing documentary and melodrama side by side so that the emotional rollercoaster effect is extended. Like many postmodernist media texts, Holmes on Homes creates a pastiche of genres. The documentary elements of the show are fairly straightforward: as stated earlier, the explicit interviews conducted by the host/narrator, with the witness/client accounts of "what happened," are told to an implied, off-screen interviewer/television producer. In this production context, the style of documentary interview functions similarly to what Mary Ann Doane (1990) has identified as the "information, crisis and catastrophe" model of television news reportage. Doane claims that television news "fills time with events" (p. 222), which produce these "three different modes of apprehending the event" (Doane, 1990, p. 223). In her argument, the medium itself is crucial to the significance of the event depicted. Doane suggests that it is the organization of television time and "the celebration of the instantaneous," as much as what it depicts, that creates the immediacy of the moment depicted (1990, p. 222).

The production contexts of a news story and a reality television program often overlap in this respect: production crews are dispatched to capture a critical moment on the fly. This obviously does not make these two forms of "news" equally catastrophic. Rather, Holmes on Homes is built on and emphasizes the 
"felt crisis" of the homeowner, and it is information-heavy to extend the perceived value of the expert witness, Holmes himself. Holmes, as narrator, foregrounds informational aspects of the home's structural problems and solutions with the pretext of educating the homeowners, the audience, and his young team about proper renovation procedures. Yet in redeploying the documentary strategy of witness accounts, Holmes on Homes borrows crisis equity from unmediated reality to convey the same sense of urgency to a renovation gone wrong. In other words, the home "disaster" is described in visual and aural language that is similar to a breaking news story or a witness account within a documentary film. The show blends the rhetoric of information, crisis, and (impending) catastrophe to exact strong reactions from the viewer. Holmes himself guides us through the documentary evidence of the problem, and while its repair is conveyed in a tone usually associated with the excesses of melodrama, it is also not unfamiliar to the documentary. ${ }^{9}$

In blending genres, Holmes on Homes is equally concerned with melodrama's aim to locate and articulate the "moral occult" of home renovation (Brooks, 1976, p. 18). The documentary effect is balanced with the melodramatic tone of the series; thus "renovations gone wrong" becomes the primary narrative obstacle, but not in the sense of reality TV's "stories of transformation" (Hill, 2005). Rather, the obstacle operates as a pretext for the melodramatic rescue Holmes performs. This is more in keeping with Northrop Frye's (2006) description of the central theme of melodrama as "the triumph of moral virtue over villainy, and the consequent idealizing of the moral views assumed to be held by the audience" (p. 163). While Frye claims condescendingly that audiences do not take melodrama seriously enough to do them any real harm, Peter Brooks (1976), in contrast, argues that the melodrama's dramatization of a villainous nightmare world is quite personal and worthy of greater attention. Brooks contends that its origins in the popular theatre of the middle class make it "radically democratic, striving to makes its representations clear and legible to everyone" (1976, p. 15). In many ways the home improvement genre, and Holmes on Homes in particular, is merely an updated version of the middle-class theatre to which Brooks refers.

As Williams (2002) argues, melodrama's blend of pathos and action often results in excruciatingly extended moments depicting the unfair treatment of the morally righteous protagonist. This is done in part to ensure that audiences understand that their values are being affirmed through dramatization. Geoffrey NowellSmith (1991) argues:

In so far as melodrama, like realism, supposes a world of equals, a democracy within the bourgeois strata (alias bourgeois democracy), it also supposes a world without the exercise of social power. The address is to an audience which does not think of itself as possessed of power (but neither radically dispossessed, disinherited, oppressed) and the world of the subject matter is likewise one [in] which only middling power relations are present. The characters . . occupy a middle ground, exercising local power or suffering local powerlessness. . . The locus of power is the family and individual private property. (pp. 269-270) 
Homeowners' troubles are given centre stage so that they and Holmes can share in the spotlight of seeing justice served. In Holmes on Homes, the purpose of "breaking down the mechanisms of repression" (Brooks, 1976, p. 41) that may otherwise obscure the significance of these ordinary events provides a corrective to the pitfalls of following a mass consumer trend blithely. According to Mark Pupo, the perils of home renovation are real:

The Greater Toronto Home Builders' Association reports that we spent

$\$ 4.12$ billion on home improvement in 2003. But of the estimated 1,000 renovation companies in the city, only 260 are licensed. The municipal licensing and standards department at city hall receives 105 complaints about fraud and dirty practices each year. (2005, p. 44)

In Holmes on Homes, the host provides the audience with cues for moral outrage over this state of affairs, in contrast with the monotone recitation of the problem by becalmed homeowners. Holmes' emotion, coupled with the homeowners' apparent lack of emotion, invites viewers to invest personally in the show's highminded outcome. Homeowners appear calm-reasonably so, since Holmes has arrived to solve their problems. Yet when juxtaposed with Holmes' stronger reactions, both reactions comes off as more extreme. In keeping with the documentary's appeal to truth while engendering identification, this kind of approach serves a rhetorical and perhaps paradoxical purpose: to convey a sense of interested objectivity to the story. Strategies of oscillation between emotional extremes are familiar conventions of melodrama, but they are not how we may expect to engage with documentary; in this case, as viewers, we also come to identify with the plight of the "real life" homeowner while following Holmes on his crusade to rid our world of evil contractors. Once the problem can be articulated, displayed, and rectified, the "society of decent people is re-affirmed" (Frye, 2006, p. 18).

\section{Holmes on Homes: Bridging the past and future}

While the specific subgenre of home repair may be peaking on commercial television, there is nothing new about home improvement television, per se. Nearly every home renovation program airing today is indebted to the seminal program in the genre, This Old House, which was produced by PBS Boston in 1979. In This Old House, host Bob Vila and his tradesmen were craftsmen who offered substantial step-by-step guidelines to "home improvement and remodelling," as it was called. The tradesmen were presented as gentlemen and professionals; each project, and the manner in which it was tackled, embodied integrity and remained true to the show's pedagogical roots, embedded in its public-broadcasting mandate.

This Old House was a noble undertaking for at least three reasons: first, its goal was to salvage a ruined historic home and restore it to its former glory; second, representing this process on PBS placed the show within the realm of documentary; and third, because the show was ad-free, there were no counter-discourses to muddy its altruistic aims, and its documentary value (knowledge, history) was thus enhanced (Nichols, 1991). This Old House had the liberty of highlighting in great detail the work of craftspeople rather than focusing on a sponsor's products, which is not the case with reality TV. For its time, it 
also represented what can only be described as an elite endeavour: renovations for the privileged in the edifying name of residential historic preservation. Bob Vila only travelled the high road, and his merry band of gentlemen-tradesmen were humble, modest, and hard working, delivering nothing but the best to their well-heeled clients. Both the domestic space and television production have changed radically since 1979 , perhaps creating the need for a renovation saviour like Mike Holmes.

Holmes on Homes taps into the upsurge in home renovation, the one first popularized through This Old House. Home renovations - even those done badly or on the cheap - are a relatively recent luxury for working families. As a popular fad that has spanned the last decade, it is discernible in the proliferation of not only home renovation and decorating shows, but advertising and how-to materials in all media that suggest a rise of home ownership for profit. Promotions for everything from do-it-yourself projects to home decorating and major renovations suggest to consumers that this is an appropriate use of any disposable income they may have (Foege, 2002). The rise of home improvement culture also invites the working and middle classes to join the ranks of the privileged.

In contrast with Bob Vila, in the person of Mike Holmes, the image of the television contractor has soared to a new place of importance. In the melodramatic spectacle of the good life gone wrong, an entire industry of renovation rescue has been created. As Holmes himself describes it on his website:

I've been fixing a lot of sloppy, lazy and dangerous work for the past two decades. I think it's time to expose the work of these so-called contractors and help homeowners make informed decisions. I want to raise the bar of the construction industry and stop the slow death of craftsmanship in this country.

In repairing wounded houses, Mike Holmes also rehabilitates and updates the tarnished masculine and professional image of the contractor, dragged asunder by unscrupulous contractors and fraudulent poseurs. His persona bridges all that is good about the past while bringing us into the present, a gesture described as melodrama's modernizing effect (Williams, 2002). The superhero contractor understands the traditional value of the home as a shelter worth maintaining. As melodrama's agent of (post)modern transition, however, Holmes is also keenly aware of the value of his own image. He pitches in on projects and assesses the status of the renovation's repairs throughout the episode. He underplays the managerial role of the contractor and focuses on notions such as honour, ethics, and right and wrong. Using these strategies borrowed from melodrama, Holmes becomes a hero to the homeowner. In the world of home improvement reality television, he serves this ideal role of the melodramatic, virtuous protagonist for the consumer of shelter culture-both the one depicted within the show and the one watching.

Holmes, like the virtuous protagonist of melodrama, identifies his highminded goal and the obstacles in his path, but he has another mission that is equally important to the success of the program: to repair the image of reality television. As I have argued previously in an unpublished conference paper, the reality genre has produced an intriguing television hybrid in the home improvement 
and renovation subgenre, embodying what Todd Gitlin (2000) refers to as television's recombinant nature. Holmes on Homes' "bare-bones" style of the home renovation subgenre distinguishes it from many others within and outside of Canada. The show domesticates reality television's blend of fictional and non-fictional elements, in part by presenting information as an informal interview/conversation, captured in what seems like a deliberately low-budget style produced by a hand-held camera. To initiate identification processes, Holmes addresses the audience member as both a privileged observer and a potential client, but this also performs the task of all commercial television, which is, according to Ien Ang (1991), the delivery of audiences to advertisers. In completing the circuitous logic - the raison d'être of TV - that links products and consumers via conventional identification strategies of television narrative, the show forges the strongest link between the ideas of improving one's home and improving one's lot in life. The docu-melodramatic structure of Holmes on Homes suggests that there is an underlying moral impulse to the renovation scenarios depicted onscreen and makes them accessible to us. Peter Brooks describes this process as transformative, because it suggests "a realm which in quotidian existence may appear closed off from us, but which we must accede to since it is the realm of meaning and value" (1976, p. 5).

In the elaborate mise-en-scènes of desire that are depicted in home improvement reality TV, "real homes" become sites for larger social issues. As mentioned previously, in Holmes on Homes, a program that deals with renovation and not decoration, structural issues concerning the home are the leading cause of anxiety. Fear of what lies within the walls and what may or may not support them drives the narrative of discovery and transformation, but these often seem to be overstated and misplaced anxieties that are remedied by overkill repairs Holmes and his team carry out for the purpose of performing his outrage and remediation.

Holmes makes much of renovations that were done without building permits and also makes disparaging comments about the minimal code requirements that home inspectors must adhere to in order to approve work done by contractors. Instead, the team - at Holmes' behest - will often go to great lengths to exceed building code requirements, in order to elevate the home renovations done by the Holmes team and to point out the range of legal but unacceptable renovations. The undue emphasis on the home as a (potential or existent) site of catastrophe fits within Doane's scheme of creating meaningful televisual time, but the overdetermined and displaced anxiety is similar to the fear of the external world that Linda Williams (2002) has identified in earlier melodramatic literary traditions. Williams argues that the moral occult is sometimes difficult to locate within the home, and ultimately the external world cannot be controlled. Thus the recurring "threat" to the home becomes a means of filtering other unspoken fears and anxieties.

Williams locates the perceived threat to home (and family) within the racist imagination of White, middle-class Americans following the Civil War as primarily a fear of the idea of racial integration. It is often the case that melodramas present anxieties concerning modernization and social transition in a format that is palatable to the middle class. ${ }^{10}$ In Holmes on Homes, the threat of bad home 
renovation by fly-by-night or incompetent contractors is presented as a subtle form of class and gender panic. By comparison, Canadian home invasion fears are less dramatic and assuaged easily by Holmes' professionalism. It is also telling that he "knows his place" as a contractor and corrector of misdeeds - in contrast with those presented by inference as evil, working-class men whom middle-class homeowners fear, in part because they have specialized knowledge that they do not themselves possess. Holmes thus bears the burden of representation for noble, working-class masculinity as he constantly compares and is compared with those of his "brethren" whose work ethic and attitude often appear wanting in relation with his own. Yet despite the laudable work Holmes does, he also draws attention to non-problems or inflates minor problems. ${ }^{11}$

Perhaps the most recognizable working-class virtuous protagonist figures were the ones so often portrayed in the 1950s Hollywood heyday of melodrama as to-be-looked-at buff outsiders. William Holden in Picnic (1956) or Rock Hudson's roles in Douglas Sirk films - especially All That Heaven Allows (1955)—are prime examples of melodrama's working-class heroes, who save women from their home lives and thus help modify, if not thwart, conventional expectations about small-town life. In each case, these agents of modernity liberate women from the constraints of the home by offering a better alternative. Holmes, likewise, has strategically carved out a space for himself as the hero through his stated objective: "I'm gonna make it right." The challenge of the Manichean universe he inhabits is what Brooks (1976) claims "involves the confrontation of clearly identified antagonists and the expulsion of one of them" (p. 9). This sort of heroic quest fits well within the melodramatic mode, where, according to Brooks, "virtuous protagonists pursue evil men whose activities are finally revealed" (1976, p. 11) in this case, by revealing and repairing their shoddy workmanship.

The role of virtuous protagonist-superhero is not only part of Holmes' fix-it persona; it also brings along all manner of gender and sexual baggage. A column in The Toronto Star (2006) identifies the contractor as not only a hero who does honest and valuable work, but also a potential object of desire for the "lady" of the house. In the 1950s domestic melodrama, the central female protagonist, such as Jane Wyman in All That Heaven Allows, recognizes the male protagonist's physical attractiveness and ability as part and parcel of his domestic virtue. By choosing him, she confirms his heroic status for others struggling with his underclass position. But does Rock Hudson or our man Holmes ever break a sweat? Like Superman before him, Holmes has a signature costume. He is never seen without his shabby-chic brown overalls, stylized bleach-blond buzz cut, earring, and dirt-defying white undershirt, all of which make him an equally charismatic gay icon. Outdated metrosexual cachet aside, he portrays a "new" masculinity that both upholds traditional traits of manhood-independence, hero to damsels in distress - and alludes to the gay chic influence that has emerged in home show programming. Holmes, according to Steven Davey (2003), is a queer icon. In the fourth season, episodes open with a compilation of various repair projects in which homeowners extol Holmes' virtue (see Note 7). In one instance, a woman in a heterosexual couple says, "I love you, Mike Holmes." In the background, her husband chimes in, "Me too!" 
Holmes is the ultimate postmodern contractor/narrator and fits contemporary versions of masculinity such as those described by Mary Blewitt (1988), who identifies the transition of the trades to the modern era of working-class masculinity in terms of geographic and gender mobility. In Blewitt's terminology, Holmes straddles "active displays of male self-assertion" while embodying the "largely passive appreciation of male 'role models' or 'stars"' (Blewitt in Mullin, 2002, p. 3). The men who do the work with Holmes are fairly mute, except when they explain or confirm what he says or wants done. They may be his emerging protégés, but Holmes is ultimately the only virtuous protagonist awaiting recognition. He is the "new man": equally comfortable proving his manliness or just sitting back as an object of appreciation.

\section{Conclusion}

What's in store for our superhero, Holmes? The 2006-2007 ad campaign I referenced earlier in this article suggests that Holmes on Homes is well prepared to transform again for future re-purposing. Both the rapid animated montage fragment and the freeze-frame transition from live action to animation extend the brand image by relating the ad's comic-book style to an overall process of ideal modernization of consumer culture, which Holmes himself embodies. Yet this is more than a creative flourish. The advertisement digitizes and animates each liveaction image of Holmes on the go, and by association it suggests that, like the technology used to portray him, Holmes is cutting-edge. While Holmes conveys that he is "in the know" about renovation repairs, the digitally manipulated image becomes an introduction to what might be called the show's "television of attraction." This "attraction" is due to the fact that the program showcases both a variety of high-end renovation technologies in the tools Holmes employs, from building materials to the laser level, as well as in the hand-held televisual apparatuses that permit close access to the subject and help convey the immediacy and documentary appeal of the reality TV genre. While the advertisement emphasizes an important connection with the overall commodification of Holmes' image and universe, it also overtly links the image of the contractor with the idea of the hero. And if all ads consolidate a brand identity, these suggest that Holmes is more than a helpful heroic fix-it man to Canadian homeowners, the guy who will "make it right." Like any good superhero, Holmes is on a mission - in this case, to stamp out disreputable or incompetent contractors, or evil-doers, who litter the construction landscape and to make the home improvement sector safe for all consumers.

Is there a level of built-in obsolescence in this comic-book-superhero image of Holmes, or can he be retrofitted beyond his association with the virtuous working-class protagonist of melodrama? With 1950s melodramatic cinema, as critical social conditions changed, audiences seemed to tire of over-the-top emotions and tear-jerker excess. But melodrama is nothing if not historically promiscuous: it found its way into other film genres of the period. And as David Thorburn (2000) has argued, melodrama did not go away; it just migrated (along with Hollywood studio production) to TV. It is perhaps television's overall indebtedness to the melodramatic mode and reality TV's seemingly endless ability to recombine genres and transform itself via new spin-offs that point out this tendency so clearly. Will the mutations and transformation of the reality genre of TV 
ever end? And what of Mike Holmes' position in the renovation genre? Will he remain a star? Will the goals of the Holmes Foundation be realized and end the need for this superhero to intervene in renovation disasters?

Maybe. Holmes on Homes extends its shelf life in part by migrating to networks other than HGTV. The program is also available online, where you can watch a portion of an episode you may have missed or contribute to one of Mike Holmes' charities. But while this interactive medium may be providing an inviting new home within which the comic-book superhero and virtuous protagonist of melodrama can co-habitate, Holmes has again moved on to other projects. Holmes has jumped on the environmentalist bandwagon, which has acquired its own niche in the world of HGTV programming. This may seem somewhat ironic, given how much building material viewers have witnessed him ripping out and throwing away over the years. Holmes' company is now building environmentally friendly, sustainable housing that is energy efficient and modest. In a June 2008 interview on CBC's The Hour, George Stroumboulopoulos asked about the Alberta housing project Wind Walk that Holmes has initiated, and Holmes argued that it was really a community he was building, where relatively inexpensive homes could stand the test of time and where like-minded people could come together and make a neighbourhood from these altruistic goals.

By now this process of engagement in televisual reality is a familiar ritual. As Brooks claims of melodrama,

[it is] not a metaphysical system, it is rather the repository of the fragmentary and de-sacralized remnants of sacred myth. It bears comparison to unconscious mind, for it is a sphere of being where our most basic desires and inner dictions lie. (1976, p. 18)

Holmes on Homes is an extremely popular Canadian example of the ritual of home improvement reality TV. It refigures the arrangement between fiction and non-fictional elements of reality television drawn from the CRTC licensing and policy mandate while retrieving the emotive reality associated with classic melodrama and the documentary. The show taps into nostalgic and utopian ideals of nation, class, and masculinity; its postmodernist representational modes serve the twin gods of commerce and culture, as well as those desires for the justice and redemption imagined for "ordinary" middle-class Canadians.

\section{Acknowledgments}

This special issue was originally conceived with Renée Sgroi. Many thanks to Kim Sawchuk for her excellent editorial suggestions and contributions, as well as her kind and unwavering support. Thanks also for the incisive observations of Andrea Zeffiro, editorial assistant, and skillful wordsmithing of Maureen Gillis and Marilyn Bittman, copy editors.

\section{Notes}

1. HGTV Canada alone is involved in the production of 12 to 15 featured programs per year, while HGTV International boasts more than 100 shows in its line-up.

2. Holmes on Homes has been ranked consistently at the top of all HGTV Canada shows (or close to it) in ratings since 2001. It received the Viewer's Choice Gemini Award in 2004. Holmes on Homes can now also be seen in Canada on The Life Network and BBC Canada. Holmes was recently "recognized by the House of Commons for the promotion of skilled trades and advocacy for improved building standards" (http://www.holmesonhomes.com/index.php). 
3. This effectively allowed "local" Canadian content to retain its position at the forefront of debates, while the "global" lines governing genre, such as those distinguishing dramas from documentaries, were being redrawn to reflect the "glocalization" of reality television production.

4. The full commercial from 2005-2006 is as follows:

Announcer (voice-over, a voice that is familiar to HGTV Canada viewers, as it is heard often on ads for the network and its individual programs): "You called for a contractor, what you got was a hero. It's the mighty Mike Holmes."

Close-up of Mike Holmes: "I'm gonna make it right."

Announcer: "Rescuing homeowners from renovation disaster ..."

Meanwhile, an animated photo-montage is shown, featuring our blond buzz-cut hero in brown overalls and work boots swinging into action, Tarzan-like, with said "homeowner," a woman, tucked under his arm in damsel-in-distress mode. Next, live-action imagery of various repairs to renovations gone wrong.

Medium close-up of Holmes: "What the hell is this?

"These guys should be out of business.

"They don't wanna deal with me."

Announcer: "... saving the day every chance he gets."

Cut to live-action imagery. Three shots of different 30- to 50-year-old women in medium close-up extolling the virtues of Mike Holmes' work.

"I love it. It is fabulous."

"This is to die for!"

"I do have faith in Holmes on Homes."

The following is intercut with images of Holmes smiling, chuckling, and working.

Announcer: "See Mike in action every week."

Holmes: "Let's do it!"

Image of Mike Holmes nodding his head, standing cross-armed in white undershirt and brown overalls with tool belt.

HGTV logo appears.

Announcer: "Holmes on Homes, Thursday night at 8 on HGTV."

5. Whether this discussion does occur off-screen is not the point. The choice to position Holmes publicly via the program as a benevolent purveyor of renovation largesse increases our sense of his heroism and virtue.

6. Vincente Minnelli's The Cobweb (1955) is an excellent example of a melodrama, in which the creation of new draperies for a sitting room in a mental institution becomes the nexus for all kinds of social, personal, and familial anxieties occurring inside and outside of the immediate setting.

7. The overwhelming evidence on reality television suggests that designing and decorating are the purview of women and gay men. Holmes seems very interested in distinguishing himself from these groups, yet he is not always successful in doing so, as I later argue. For example, at the end of a "reveal," Holmes is often seen hugging the woman of the house as the homeowners thank him. He makes much of not wanting to hug the men - who somehow always want to hug him! When he does "agree" to be hugged by a man, he refers to it as a "man hug" and gets it over with as quickly as possible. In one episode featuring an obviously gay male couple, the subject of hugging does not come up at all. Every other episode has hugging as part of the show's convention of thanking Holmes. In one episode featuring an elderly woman and her daughter, Holmes "endures" the repeated hugs and kisses from the older woman. Sexuality is highly monitored on Holmes on Homes, and since hugging borders between affection and sex, its meanings must be regulated and the sexual dimension downplayed where deemed socially inappropriate, as in the examples discussed. In two early episodes involving young, attractive heterosexual couples, however, the lines between love, affection, and sex are not as clear as they might be. In one case, while the woman and Holmes hug, he comments, "God, I love my job." In another, the woman says, "I love you, Mike Holmes." Meanwhile, in the background the husband says, "Me too!" in response to his wife's declaration. These last extracts are often used to advertise the program. 
8. This paper is part of a larger research project on Canadian home improvement television in which I discuss the "money shot" of the reveal and the verbal/visceral responses (the "oohs and ahs" and the tears) in relation to pornography and melodrama (cf. Williams, 1991).

9. See Housing Problems (Anstey \& Elton, 1935) for an early example of a socially responsible documentary with commercial (advertising) interests and melodramatic overtones.

10. See also D. W. Griffith's Birth of a Nation (1915). This film is only the most explicit example of the idea of the threat to the home as a metaphor for racial purity. Several of Griffith's other melodramas present the home as the site of class and gender conflict.

11. In conversation with an excellent contractor, I had the opportunity to discuss Holmes on Homes. One of the carpenters working with him, commented specifically on the show's overkill as the major reason he did not like the program: "For Mike Holmes, a popped drywall screw doesn't mean you have to replace and patch it. It means you have to tear out all the drywall and start again or the house may fall down" (personal communication, Kingston, ON, July 13, 2007).

\section{References}

Ang, Ien. (1991). Desperately seeking the audience. London, UK: Routledge.

Anstey, Edgar, \& Elton, Arthur. (1935). Housing problems. [Film, 15 min.] British Commercial Gas Association.

Blewitt, Mary. (1988). Men, Women and Work: Class, Gender and Protest in the New England Shoe Industry, 1780-1910. Urbana, Il: University of Illinois Press.

Bratton, Jacky, Cook, Jim, \& Gledhill, Christine. (Eds.). (1994). Melodrama: Stage, picture, screen. London, UK: BFI.

Brooks, Peter. (1976). The melodramatic imagination: Balzac, Henry James, melodrama, and the mode of excess. New Haven, CT: Yale University Press.

Bruzzi, Stella. (2006). New Documentary. (Second Edition) London: Routledge.

Canadian Radio-television and Telecommunications Commission. (1996). CRTC. URL: http://www.crtc.gc.ca/eng/archive/1996/ DB96-607.htm [March 3, 2009].

Canadian Radio-television and Telecommunications Commission. (1999). CRTC. URL: http://www.crtc.gc.ca/eng/archive/1999/ PB99-206.htm [March 3, 2009].

Davey, Steven. (2003). Homes for homos. Now, 22(44). URL: http://www .nowtoronto.com/lifestyle/story.cfm? content $=137189 \&$ archive $=22,44,2003$ [August, 13, 2007].

Doane, Mary Ann. (1990). Information, crisis, catastrophe. In P. Mellencamp (Ed.), Logics of television: Essays in cultural criticism, pp. 222-49. Bloomington, IN: Indiana University Press.

Elsaesser, Thomas. (1991). Tales of sound and fury: Observations on the family melodrama. In Marcia Landy, (Ed.), Imitations of life: A reader on film and television (pp. 68-91). Detroit, MI: Wayne State University Press. (Originally published in 1972)

Everett, Anna. (2004). Trading private and public spaces@ HGTV and TLC: On new genre formations in transformation TV. Journal of Visual Culture, 3(2), 157-181.

Foege, Alec. (2002, July 15-22). Fix-it fixation. Mediaweek, pp. 20-26.

Frye, Northrop. (2006). Towards a theory of cultural history. In G. Warketin (Ed.), Collected works of Northrop Frye, Vol. 21: The educated imagination and other writings on critical theory 1933-1963, pp. 150-168. Toronto, ON: University of Toronto Press. (Originally published in 1957). 
Gitlin, Todd. (2000). Prime time ideology: The hegemonic process in television entertainment. In H. Newcomb (Ed.), Television: The critical view (6th ed.) (pp. 574-594). London, UK: Oxford University Press.

Griffith, David Wark (D.W.). (1915). The Birth of a Nation. [Film: 125 min.] David W. Griffith, Corporation.

Hill, Annette. (2005). Reality TV: Audiences and Popular Factual Television. London: Routledge.

Holmes, Mike. (2007). Make it Right. Toronto: Harper Collins Canada.

Holmes, Mike. (2008). The Holmes Inspection. Toronto: Harper Collins Canada.

Holmes, Mike, MacNeil, Scott Clark. [Executive Producers]. (2001-2005). Holmes on homes. [Television series]. Make it Right Productions, General Purpose Pictures Productions. Mike Holmes, John Fulford-Brown, Pete Kettlewell, Michael Quast, [Executive Producers].

Holmes on Homes. Website. URL: http://www.hgtv.ca/ontv/hostdetails.aspx?hostid=36939 [March 3, 2009].

Klinger, Barbara. (1994). Melodrama and Meaning: History, Culture and the Films of Douglas Sirk. Bloomington: Indiana University Press.

Logan, Joshua. (1955). Picnic. [Film: 113 min.] Fred Kohlmar, Producer. Columbia Pictures.

Mullin, Joseph. (2002). I, too, am a man: The forging of "emancipatory" masculinities in the "American" laboring classes. Ex Post Facto: Journal of the History Students at San Francisco State University, XI. URL: http://libra.sfsu.edu/ epf/2002/ mullin.html [July 7, 2008].

Nichols, Bill. (1991). Representing reality. Bloomington, IN: Indiana University Press.

Nowell-Smith, Geoffrey. (1991). Minnelli and melodrama. In M. Landy (Ed.), Imitations of life: A reader on film and television (pp. 268-274). Detroit, MI: Wayne State University Press. (Originally published in 1977)

Pupo, Mark. (2005, April). Deconstructing Holmes. Toronto Life, 39(4), 43-48.

Sirk, Douglas. (1955). All That Heaven Allows. [Film: 89 min.] Ross Hunter, Producer. Hollywood, CA: Universal-International Studios.

Thorburn, David. (2000). Television melodrama. In H. Newcomb (Ed.), Television: The critical view (6th ed.) (pp. 595-608). London, UK: Oxford University Press.

The Toronto Star. (2006, September 28). p. L1, L5.

Williams, Linda. (2002). Playing the race card: Melodramas of black and white from Uncle Tom to O. J. Simpson. Princeton, NJ: Princeton University Press.

Williams, Linda. (2004). Film bodies: Gender, genre, and excess. In L. Braudy \& M. Cohen (Eds.), Film theory and criticism (6th ed.) (pp. 727-741). London, UK: Oxford University Press. (Originally published in 1991) 